\title{
Empirical Evidence on CEO Reputation: Perspectives, Actions and Influence
}

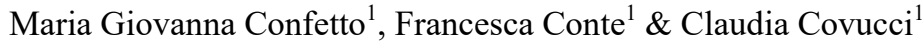 \\ ${ }^{1}$ Department of Political, Social and Communication Sciences, University of Salerno, Italy \\ Correspondence: Maria Giovanna Confetto, Department of Political, Social and Communication Sciences, \\ University of Salerno, Italy. E-mail: mconfetto@unisa.it
}

Received: September 28, 2018

Accepted: October 29, 2018

Online Published: November 20, 2018

doi:10.5539/ijbm.v13n12p215

URL: https://doi.org/10.5539/ijbm.v13n12p215

\begin{abstract}
The study aims to explore the theoretical perspective (ability or symbolic image perspective) that underlies the development of reputation of Chief Executive Officers (CEO), investigating the activities that contribute to create a leaders' good name and exploring their view about the level of influence of their personal reputation on corporate reputation. Through a structured questionnaire, a web survey has been carried out addressing CEOs of large companies located in Italy. The respondents to the survey are 93 CEOs.

The findings of the survey reveal that, according to executives' view, CEO reputation reflects individual skills (ability perspective), in which the leadership style, credibility and charisma play a key role. Furthermore, results highlight executives are aware that their reputation are increasingly intertwined with the corporate reputation, but they do not believe that the construction of a personal brand is necessary to increase their reputation and, consequently, that of the company.

The study sheds more light on the understanding of CEO's reputation role in corporate reputation development, reinforcing the value of strategic leadership perspective. It contributes to the ongoing debate on CEO reputation and involves managerial implications, pointing out advantages and risks of linking CEO branding with company's reputation.
\end{abstract}

Keywords: Chief Executive Officer, CEO reputation, corporate reputation, CEO branding

\section{Introduction}

It is widely acknowledged that the corporate reputation is crucial for obtaining and maintaining everyday stakeholders' support (Gray \& Balmer, 1998; Roberts \& Dowling, 2002; Gardberg, 2017). Hatch and Schultz (1997) stress a CEO is a "symbol of corporate identity" that has influence on what stakeholders "perceive, feel and think about the organization" (p. 363). CEOs contribute to affect top management decisions with their own personal and professional backgrounds, conducts, distinctive values and personalities (Balmer, 2001; Melewar \& Karaosmanoglu, 2006; Lo \& Fu, 2016).

Thus, CEO symbolically personifies the organization, contributing to shaping the firm's values and embodying the company's reputation (Pincus et al., 1991; Kitchen \& Laurence, 2003; Love et al., 2017).

The objective of the study, in continuity with the research of Conte (2018), is twofold. First, it aims to explore the theoretical perspective (ability or symbolic image perspective) that underlies the development of CEO reputation, investigating also the CEO activities that contribute to create a leader's good name. Secondly, the purpose of this paper is to explore CEOs' view about the level of influence of their personal reputation on corporate reputation. The study is focused on the Italian context, given the significant presence of family businesses in which CEOs, often coinciding with the company's founder, strongly affect the corporate culture (Corbetta, 2010; AIDAF, 2014).

The paper is organized as follows. The review of the literature provides the conceptual background on CEO reputation and its relation with corporate reputation and develops three research questions investigated through an exploratory survey on Italian CEOs' perceptions. Findings are then discussed, by reinforcing the strategic leadership perspective. The study concludes with theoretical and managerial implications and suggestions for future research. 


\section{Conceptual Background}

\subsection{Perspectives on CEO Reputation}

Several studies assume that the organization is a reflection of its top managers that play a pivotal role in shaping major organizational outcomes (Vera \& Crossan, 2004; Carpenter et al., 2004).

Personifying the corporate culture, the person who embodies the mission and the purpose of an organization is the CEO and his/her influence on firm's reputation is affected by stakeholders' assessments of leadership capabilities and characteristics (Bates, 2011). CEOs develops in fact a personal reputation, reflecting the salient personal traits, conduct, achievements and images in a certain period of time (Ferris et al., 2003, Love et al., 2017). Their reputation serves to reduce the uncertainty regarding expected future behavior of the leader (Baker $\&$ Hall, 2004), and it is a key factor for long-term success and the survival of an organization (Fuller and Jensen, 2010).

Several studies focus on two aspects of CEO reputation: a perspective which refers to executives' skills (ability perspective) and a perspective linked to their image (symbolic image perspective) (Lee, 2006). The first perspective argues that CEO reputation reflects the individual abilities that have an influence on corporate performance (Daily \& Johnson, 1997; Chang et al., 2010; Baik et al., 2011). CEOs with high reputation demonstrate competence, integrity, reliability and charisma (Park and Berger, 2004). The symbolic image perspective states that CEO reputation is the personal image perceived by stakeholders and, above all, created by the use of the media. "Image" is the overall mental picture one has about a person. According to Fetscherin (2015), CEO image reflects the perception of the persona and the personality by public opinion, considered beyond his/her prestige and performance as company's leader. In this regard, when personal CEO communication activities are assimilated into corporate communication efforts at all levels, we talk about CEO positioning (Zerfass et al., 2016) or CEO branding (Bendisch et al., 2013; Fetscherin, 2015; Davis, 2015). "When CEO's are in the public domain, their brand and that of the company they represent are considered together and therefore influence each other» (Bendisch et al. 2011, p. 597). Creating a brand around the person of the CEO that is aligned with that of the company thus becomes fundamental. In this process, the use of the media - also for personal purposes - can play a key role in the perception of brand value by the public (Busenbark et al., 2016; Conner, 2018).

Although these two perspectives linked to CEO reputation have been studied in literature, they have never been empirically found, considering CEO's self-perception. Moreover, despite the growing focus on the CEO reputation issues, few studies have investigated the actions taken by executives and the key qualities able to create and improve the CEO reputation, so the first and the second research questions of this study are:

RQ1: which perspective (ability perspective or symbolic image perspective) underlies the development of CEO reputation?

RQ2: which CEO actions tend to create and improve his/her reputation?

\subsection{The Influence of CEO Reputation on Corporate Reputation}

The conducts, behavior and communications of CEOs are critical factors in corporate reputation building (Gaines-Ross, 2000; 2003; Murray \& White, 2005; Sohn et al., 2009; Weng \& Chen, 2017).

A growing body of research indicates that the reputation of leaders influences the perceptions of the organization among stakeholders, and thereby organizational reputation (Kitchen \& Laurence, 2003; Meng \& Berger, 2013). CEO is "the face and the voice" of the organization (Ferns et al., 2008, p. 121), when the CEO speaks is the company that speaks (Gainess Ross, 2008). CEO, above all if is also the company's founder, exerts a strong influence on the creation and sharing of corporate vision (Balmer, 2001). Hence, his/her reputation plays a decisive role in the assessment of long-term business success as, by representing the company's values and culture, consequently his/her reputation affects corporate performance (Milbourn, 2003; Karuna, 2009).

CEO can build over time a real personal brand (Power, 2005; Ulrich and Smallwood 2007; Rampersad, 2009; Bates, 2011). Through their personal engagement with public, CEOs can increase leaders' prominence and influence perceptions of their quality (Hamilton \& Zeckhauser, 2004; Malmendier \& Tate, 2005; Love et al., 2016), affecting also the corporate reputation, in a positive as well as a negative way. Specifically, CEO creates his/her own brand when he/she develops a distinctive leadership capable of shaping organizations' values (Rampersad, 2009). The CEO brand is expressed mainly through a set of symbolic and intangible elements deriving from personal attitudes, experiences, skills and culture. The value of CEO's brand is influenced by the way people perceive the authoritativeness and the charisma of the leader: it depends on the effectiveness of the communication flows activated by CEO that must be authentic and credible. In fact, the credibility in CEO 
communication is an essential factor for building a strong personal brand and consolidating trust with stakeholders (Men, 2012).

Thus, CEO and company reputation are inextricably linked - corporate reputation is not isolated from the public's views of a company's top leadership. Together, company and CEO reputation make a solid contribution to a firm's market value. Corporate reputation benefits from the positive effects of an excellent leader, but there is also a strong risk: the constant need to control his/her own personal image in order to fulfil the responsibilities as a CEO, can result in "role stress", especially if expectations of the CEO identity conflict with personal values. The result is that CEO may behave in an way that can damage the perceived value of his/her brand (Bendisch et al., 2013). In this case, public opinion may not be able to unravel this strong link between the reputation of the leader and that of the company. Therefore, it becomes inevitable to reflect the negativity associated with the individual on the organization he/she represents. Think of the combination in the minds of the public between the Tesla brand and its founder Elon Musk. The success or failure of Tesla - and its reputation - has become synonymous with the success or failure of Elon Musk. For this reason, his narcissism and often irritating and inopportune tweets have had an immediate negative impact on Tesla's corporate reputation (Ladd, 2018).

Although the close relationship between corporate reputation and CEO reputation could represent a risk factor for the company (Fry, 1997), the CEO brand is a key factor to affirm the personal image and "humanize the face of the corporation". Indeed, a positive CEO brand can not only support the consumers' decision to purchase good/service and favor good performance in the company's stock market, but it can also motivate and encourage employees (Bailey, 2010).

The close link between CEO reputation and corporate reputation is supported also by empirical studies (Shane and Cable, 2002; Rindova et al., 2005). In USA, a survey by Burson-Marsteller (2003) shows that the CEO reputation plays an important role in the overall assessment of an organization: the relevance of the CEO in the company's reputation has increased over time and over $90 \%$ of financial analysts recommended stocks considering the reputation of CEO (Gaines-Ross, 2003). According to the study of the GCI Group, conducted on 250 students of economics in United States and the United Kingdom, $76 \%$ of respondents associate the reputation of a company to its CEO (Feldman, 2004).

Specifically in the Italian context, the relationship between CEO reputation and corporate reputation has received little empirical attention. In this respect, the study undertaken by Hill \& Knowlton underlines that CEO's role is among the main factor in influencing corporate reputation and CEO reputation has a greater relevance in Italy (Kitchen and Laurence, 2003). Also the research of Conte (2018) shows that Italian CEOs are aware of the importance of their reputation in contributing to the development of company's reputation. However, in order to have a more detailed view on this relationship, it is advisable to deepen further the self-perception of CEO on the influence of his/her own role - and then reputation - in developing corporate reputation, thus the third research question is:

RQ3: according to CEOs' view, how much CEO reputation affects corporate reputation?

\section{Methodology}

The present study is in continuity with the research undertaken in Conte (2018), whereby the methodological approach and the sample are the same. In order to investigate the CEOs' perceptions of their role in corporate reputation, a structured questionnaire was addressed to 349 CEOs of companies located in Italy, selected from Mediobanca 2015 report (Note 1) $)^{1}$. A total of 93 CEOs responded to the survey corresponding to a $26.7 \%$ response rate which is line with other studies investigating similar populations, such as top managers (Waldman et al., 2006).

The survey was generated by questions and items from the extant literature with a deductive approach in order to ensure an adequate representation of the domains of interest within our field of research (Jian et al., 2014). Table 1 points out the three research questions investigated in the paper, the topics on which they focus, and the items analyzed (i.e. the number of issues submitted to CEOs). In the last column the table presents the references from which the items were derived.

\footnotetext{
${ }^{1}$ This report contains 1497 companies who achieved an annual turnover of at least 50 million euros. Company representatives from the branches of the group and business-to-business companies (665) were excluded from the analysis due to their limited corporate awareness of the general public (for a total of 832 companies). The unit of analysis was randomly drawn from that resulting population.
} 
Table 1. Research questions, survey questions, number of items and references

\begin{tabular}{|c|c|c|c|}
\hline Research questions & Survey questions focus & $\begin{array}{l}\text { No. of } \\
\text { items }\end{array}$ & References \\
\hline $\begin{array}{l}\text { RQ1: which perspective } \\
\text { (ability perspective or } \\
\text { symbolic image perspective) } \\
\text { underlie the development of } \\
\text { CEO reputation? }\end{array}$ & $\begin{array}{l}\text { Type of perspective that } \\
\text { justify CEO reputation } \\
\text { building }\end{array}$ & 2 & $\begin{array}{l}\text { Hayward et al., 2004; } \\
\text { Malmendier and Tate, 2005; } \\
\text { Chang et al., 2010; Baik et } \\
\text { al., } 2011\end{array}$ \\
\hline $\begin{array}{l}\text { RQ2: which CEO actions } \\
\text { tend to create and improve } \\
\text { his/her reputation? }\end{array}$ & $\begin{array}{l}\text { Type of activities that } \\
\text { contribute to CEO } \\
\text { reputation development }\end{array}$ & 5 & Reputation Institute, 2017 \\
\hline $\begin{array}{l}\text { RQ3. according to CEOs' } \\
\text { view, how much CEO } \\
\text { reputation affects corporate } \\
\text { reputation? }\end{array}$ & $\begin{array}{l}\text { Statements that support } \\
\text { the link between CEO } \\
\text { reputation and Corporate } \\
\text { reputation }\end{array}$ & 6 & $\begin{array}{l}\text { Fry, 1997; Balmer, 2001; } \\
\text { Gainess Ross, 2008; Kitchen } \\
\text { and Lawrence, 2003; } \\
\text { Milbourn, 2003; Bates, } 2011 .\end{array}$ \\
\hline
\end{tabular}

For RQ1, the survey questions aim to investigate the type of perspective (ability or symbolic image -2 items) that underlies CEO reputation development, considering the approaches derived to literature (Hayward et al., 2004; Malmendier and Tate, 2005; Chang et al., 2010; Baik et al., 2011). For RQ2, the survey questions examine the actions undertaken by CEOs to improve their personal reputation, taking into account some of the dimensions of RepTrak Pulse (Reputation Institute, 2017) that can be connected to the CEO's activities: leadership, performance, governance, citizenship, workplace (5 items). Lastly, for RQ3, the study analyses the relation between CEO reputation and corporate reputation, considering various contributions to this regard (Fry, 1997; Balmer, 2001; Gainess Ross, 2008; Kitchen and Lawrence, 2003; Milbourn, 2003; Bates, 2011). In particular, the survey questions focus on statements regarding: the link between the corporate vision and the personality of executives; the CEO's role for long-term business success; the need to build the CEO brand; the possibility of risk conditions behind the relationship between CEO reputation and corporate reputation; the activities of leader as spokespersons of company; the influence of CEO communication and behaviors on the perception of organizations (6 items).

\section{Findings}

As reported in table 2, a clear majority of CEOs (86.4\%) agrees that the CEO reputation reflects the individual skills of executives than ensure the company's success (RQ1). Only the $13.6 \%$ of respondents claims that the CEO reputation is linked to the symbolic image created by the use of the media.

Table 2. Perspectives related to the CEO reputation development

\begin{tabular}{lc}
\hline CEO reputation perspectives & $\%$ \\
\hline CEO reputation reflects the CEO's individual abilities to ensure the success of his/her company86.4 \\
(ability perspective) \\
CEO reputation reflects the personal image created through the use of the media (symbolic image 13.6 \\
perspective) \\
Total
\end{tabular}

In order to improve the CEO reputation, according to the opinion of the respondents (see tab. 3), it is crucial to be leader and create a shared vision (82.9\%). It is also important to ensure the achievement of results $(74.4 \%)$ and to communicate transparently with stakeholders $(61 \%)$. Nearly half of the respondents believe that create relationships with employees (47.8\%) could affect the reputation of the CEO, while assuming responsibilities in crisis situations is not considered very relevant for a better CEO reputation $(32.5 \%)$. 
Table 3. CEO actions that create and improve CEO reputation

\begin{tabular}{ll}
\hline CEO actions & \% \\
\hline Be leader, creating a shared vision & 82.9 \\
Keep promises and ensure the achievement of results & 74.4 \\
Communicate transparently with stakeholders & 61.0 \\
Create relationship with employees & 47.8 \\
Assume their responsibilities in crisis situations & 32.5 \\
\hline
\end{tabular}

The responses in Table 4 show the degree of CEOs' agreement to some statements about the relation between CEO reputation and corporate reputation, while the figure 1 aggregates the answers "strongly agree" and "quite agree" of Table 4.

The $78 \%$ of CEOs strongly agree that the CEO is the spokesman for the company ("when the CEO speaks, is the company that speaks"). In particular, an appreciable percentage of CEOs $(74.6 \%$, adding "quite agree" and "strongly agree" - see figure 1) affirms that the vision of an organization becomes the projection of the ideas and personality of its founder.

Table 4. Relation between CEO reputation and corporate reputation

\begin{tabular}{|c|c|c|c|c|}
\hline Statements & $\begin{array}{l}\text { Strongly } \\
\text { disagree } \\
\% \\
\end{array}$ & $\begin{array}{l}\text { Slightly } \\
\text { agree } \\
\%\end{array}$ & $\begin{array}{l}\text { Quite } \\
\text { agree } \\
\%\end{array}$ & Strongly agree \\
\hline \multicolumn{2}{|c|}{$\begin{array}{l}\text { The vision of an organization becomes the projection of the ideas and6.8 } \\
\text { personality of its founder }\end{array}$} & 18.6 & 42.4 & 32.2 \\
\hline When the CEO speaks, is the company that speaks & 1.7 & 3.4 & 16.9 & 78.0 \\
\hline \multicolumn{2}{|c|}{$\begin{array}{l}\text { The relationship between CEO reputation and corporate reputation } 1.7 \\
\text { represents a risk for organization }\end{array}$} & 37.3 & 50.8 & 10.2 \\
\hline \multicolumn{2}{|c|}{ CEO reputation is a determining factor for long-term business success 3.4} & 22.0 & 45.8 & 28.8 \\
\hline The CEO need to build over time his own "personal brand" & 16.9 & 47.5 & 28.8 & 6.8 \\
\hline \multicolumn{2}{|c|}{$\begin{array}{l}\text { The communication flows and behaviors of the CEO influence the. } 0 \\
\text { perception of the company by the stakeholders }\end{array}$} & 5.1 & 40.7 & 54.2 \\
\hline
\end{tabular}

In the view of CEOs responding to the survey, the communication flows and behaviors of CEO influence the perception of the company by the stakeholders (an agreement of $94.9 \%$, adding "quite agree" and "strongly agree" - see figure 1).

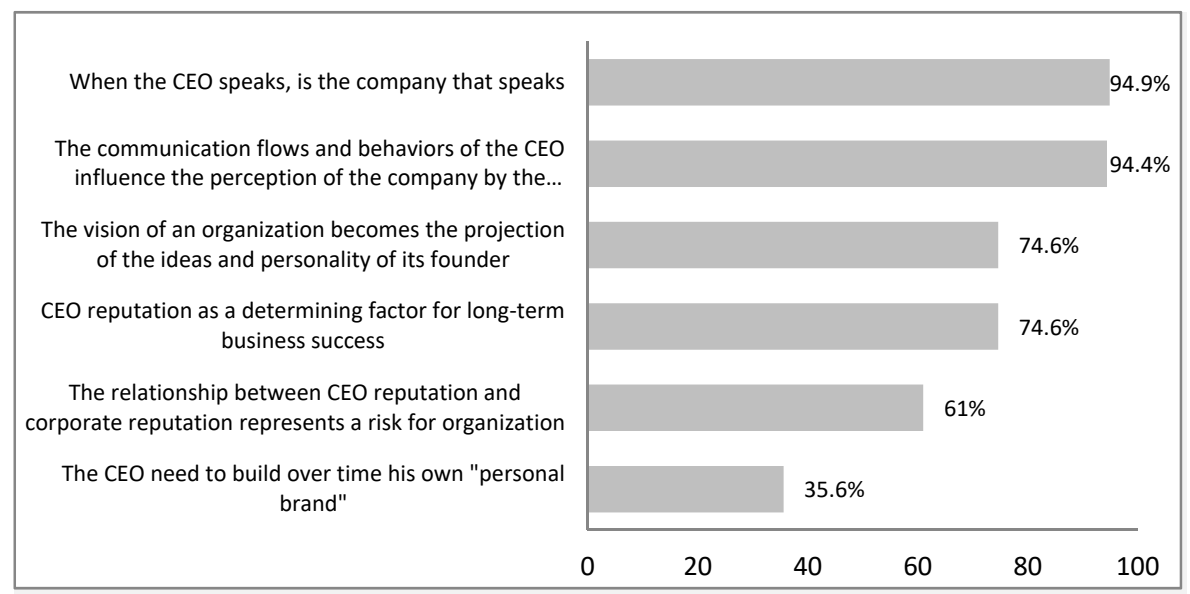

Figure 1. CEO's agreement to the statements about the relation between CEO reputation and corporate reputation

Additionally, $45.8 \%$ of CEOs claims to be in agreement that with "CEO reputation is a determining factor for long-term business success"; however, half of CEOs (50.8\% "quite agree") considers the relationship with corporate reputation as a risk element. Lastly, with regard to the necessity to create a personal brand, a good 
percentage of CEOs (47.5\%) are slightly agree.

By accumulating scores assigned to the individual indicators in table 4, a composite index was developed, thus representing a more general dimension of the degree of perceived influence of the CEO reputation on corporate reputation. The study used the procedure indicated in Babbie (2012), in order to ensure that all selected items had a logical validity and provided an adequate amount of variance (p. 167). The study obtained both an appropriate range of measurement in the index and a sufficient number of cases at each point (see table 5).

Table 5. The influence of CEO reputation on corporate reputation

\begin{tabular}{ll}
\hline Influence & $\%$ \\
\hline Low & 13.6 \\
Moderate & 13.6 \\
High & 72.9 \\
Total & 100.0 \\
\hline
\end{tabular}

Most of the respondents (72.9\%) believe that the CEO, with his/her behaviors, communications and personal reputation, strongly influences the perception of the company by the stakeholders, and as a consequence these factors have a strong impact on corporate reputation. Only a small part of CEOs perceives such influence as "not relevant" (13.6\%), or "moderate" (13.6\%).

\section{Discussion}

The study tackles the increasing importance of the CEO's role in large companies, providing new insights in the field of CEO reputation.

The finding concerning RQ1 show that, in the leaders' perception, the development of CEO reputation is related to "ability perspective". It means that their personal reputation does not derive from the symbolic image created by the use of the media, but reflects their skills in leading the company towards success. This result resonates with Milbourn (2003) that highlights as CEO reputation is essentially the market's assessment of his/her ability. Moreover, this evidence is in line with the study of Pancer et al. (1999) that stress the relevance of personality traits of leaders in determining overall evaluations of stakeholders in the political context. They emphasize the competence and the charisma factors as the key dimensions along which individuals judge the personalities of leaders. The skill factor includes intelligent, hard-working, sense of purpose and committed, while the charisma factor includes charming authority and determination (Fanelli and Misangyi, 2006).

Regarding RQ2, the study suggests that the ability to create a shared vision contributes to develop the CEO reputation. In fact, the more the CEO is able to determine the corporate culture and the formal policies of an organization (Dowling, 2001), the more the leadership role is recognized and reputation increases (Westley and Mintzberg, 1989; Waldman et al., 2001). Moreover, the study highlights that keeping the promises to the stakeholders in terms of performance achievement is determinant to the CEO's success. This is consistent with research evidences that suggest that executive's credibility is one of the most important drivers of CEO reputation (Williams, 1996, Burson-Marsteller, 2003). Ohanian (1990) argues that the key dimensions of credible CEOs are attractiveness, trustworthiness and expertise.

Findings point out that also the communication skills play a key role in the CEO reputation building. This resonates with studies in the academic and business community that have considered $\mathrm{CEO}$ as the main corporate communicator and the true symbol of corporate identity (Argenti et al., 2005; Brønn, 2014; Zerfass et al., 2014). It is clear that, even in fulfilling this task, trustworthiness is an essential requirement. Reliability is linked to authentic transparent leadership and openness in sharing truthful information and management intentions with stakeholders (Norman et al., 2010). By creating higher levels of transparency in communication, the leader and stakeholders are expected to have higher levels of trust in each other.

This result about the importance of communication with stakeholders seems to be in contradiction with that of RQ1, which instead emphasizes the belief of CEOs that are personal skills and not the image created with the use of the media to determine their reputation. In reality, it must be assumed that the importance of communicative activities towards stakeholders is to be understood by CEOs as separate from the use of media - and therefore communication - of a personal nature (CEO as an individual and not as a company's leader), as understood in the symbolic image perspective. This is consistent with the results of the empirical study of Conte et al., (2017), according to which the communication activities most important for CEOs are those of internal communication 
and institutional communication, closely related to their role as leaders.

Indeed, in communicating with stakeholders, CEO represents the firm's values, culture and personality (Campbell, 2004). In particular, the CEO engages employees by establishing an ethical climate and sense of belonging to the organization, and creates long-term and trust relations with external corporate stakeholders (Zerfass et al., 2014).

These considerations show a lack of awareness on the part of Italian CEOs of the real impact that the image resulting from the personal use of media (especially social media) has on their organization. This clarifies the strong disagreement of CEOs about the need to do personal branding (only $35 \%$ of the CEOs agreed, see figure 1). In fact, the CEO's influence on corporate reputation goes far beyond the boundaries of the organization and its administrator activity. Everything he/she does, communicates, writes, tweets, even regarding his/her personal and intimate life, reflects on the opinion that the public have of the company of which he/she is - always and anyway - the representative. From this emerges that crafting a brand strategy for CEO as the face of his/her company is arguably as important as developing the company's brand image (Pinvidic, 2018).

About RQ3, the study reveals that, according to CEOs, their personal reputation significantly influence corporate reputation. Company is closely associated with CEO's behavior and this link can alter the outcome of an organization's long-term success in establishing effective relationships with its publics (Gray and Balmer, 1998; Watson, 2007). Findings support the research on strategic leadership, sustaining that CEOs have overall responsibility for an organization and dominate the organization strategy (Hambrick and Mason,1984; Hambrick, 2007). Ireland and Hitt (2005) state that strategic leadership in the 21st century is based on determining the firm's purpose and vision, exploiting and maintaining core competences, and supporting an effective organizational culture.

In line with Kitchen and Laurence (2005) and Conte (2018) studies, the paper highlights the close link between CEO and company in Italian scenario, where above all family firms benefit from the founder CEO's close connections to stakeholders in local industrial districts (Ibrahim, 1992; Naldi et al., 2013). Thus, the personal history and experiences of CEO affect the creation, dissemination and sharing of corporate vision and the development of corporate reputation (Balmer, 2001). In this regard, Gaines-Ross (2003) defines "CEO capital" as the strategic asset created by CEO reputation that enables to access to corporate resources, as the human and market capital, increasing the firm's competitive advantage (Ranft et al., 2006).

\section{Implications, Limitations and Future Research}

The study represents a first empirical evidence to analyzing several features of CEO reputation that have not yet been fully investigated, especially in the Italian context. It first contributes to the ongoing debate on CEO's role in organizational dynamics, shedding light on the understanding of CEO's skills and activities useful to build and improve the personal reputation. Moreover, with findings on the impact of CEO reputation on corporate reputation, the study enriches the literature in this field of research, reinforcing the value of the strategic leadership perspective.

The paper also offers several managerial implications. First, it provides a reflection about the actions that CEOs must be provided for developing a strong personal reputation. In this direction, CEOs should be encouraged to participate to executive club meetings and summit aimed to share best practices and promote professional updates. The comparison between executives, the exchange of ideas and experiences, and the professional training could stimulate CEOs to develop and improve skills that contribute to create a positive reputation, such as communication abilities, open-mind vision, motivational skills.

Furthermore, this study demonstrates the influence of CEO's good name on the evaluations of the company, confirming the potential of reputation of chief communication officer as a strategic resource that organizations can leverage for achieving competitive advantages. In fact, if the leader shows consistent performances over a period of time, he/she is easily recognized and attributable as the source of corporate success. Thus, in CEOs' view, their reputation provides significant clues to the firm's future direction and performance (Carpenter et al., 2004).

In consideration of this, from this study derive possible motivations that could strongly push CEOs to work in terms of personal branding (so-called CEO branding) (Ranft et al., 2006). CEO branding implies getting the right message directly in front of the target audience, using a strategic blend of thought leadership that's demonstrated through social media, engagement's activities, publishing (e.g. owning a CEO blog) and public relations. It all starts with determining how the CEO's brand maps to the corporate brand and how it can be used to access to and conquer the target market (Davis, 2018). 
The halo effect of CEO reputation, intended as built through his/her personal communication, on the company can provide important opportunities for a company, but linking a company's reputation too heavily to a single person is risky for organizational dynamics. In fact, an unethical behavior or a wrongdoing undertaken by CEOs can damage the company's reputation (Fry, 1997). In this regard, Kartalia (1999) argues that it can take 30 years to build a reputation, yet it can be wiped out in only 30 seconds. Moreover, corporate reputation could be subject to risky situations when a CEO with a positive reputation leaves their role, causing problems in the succession processes (Shen and Cannella, 2002). Thus, CEOs should avoid that their own visibility obscures the image of the company they represents or that the two reputations are perceived as closely connected (Amerland, 2014).

One of the limits of the study is certainly related to the circumscribed sample, which should be expanded in future studies. Furthermore, it could be interesting to compare the results considering also interviews in depth that would offer different CEO's points of view depending, for example, on the business activity, the dimension and the location of the company in which CEOs operate. A comparative analysis of perceptions could also be carried out, submitting the same type of questionnaire to CEOs operating in different realities from the Italian one.

\section{References}

Adams, C. A., \& Frost, G. R. (2006). Accessibility and functionality of the corporate website: implications for sustainability reporting. Business Strategy and the Environment, 15(4), 275-287. https://doi.org/10.1002/bse.531

Corbetta, G., Minichilli, A., \& Quarato, F. (2014). Osservatorio AUB su tutte le aziende familiari italiane con ricavi superiori a 50 milioni di Euro. Retrieved from http://www.aidaf.it/wp-content/uploads/2014/08/5\%C2\%B0-Osservatorio-AUB_2013.pdf

Amerland, D. (2014). CEOs Who Blog: How To Be Your Company's Public Face. Retrieved from https://www.forbes.com/sites/netapp/2014/02/04/ceos-who-blog/\#72d915f96c8a

Argenti, P. A., Howell, R. A., \& Beck, K. A. (2005), "The strategic communication Imperative. MIT Sloan Management Review, 46(3), 83-89.

Babbie, E. R. (2012). The basics of social research (6th ed.). Wadsworth publishing company, Belmont, CA.

Baik, B. O. K., Farber, D. B., \& Lee, S. S. (2011). CEO ability and management earnings forecasts. Contemporary Accounting Research, 28(5), 1645-1668. https://doi.org/10.1111/j.1911-3846.2011.01091.x

Bailey, J. (2010). The CEO is the Brand. The power of executive communications. White paper, February.

Baker, G. P., \& Hall, B. J. (2004). CEO incentives and firm size. Journal of Labor Economics, 22(4), 767-798. https://doi.org/10.1086/423154

Balmer, J. M. T. (2001). Corporate identity, corporate branding ad corporate marketing. Seeing through the fog. European Journal of Marketing, 35(3/4), 248-291. https://doi.org/10.1108/03090560110694763

Bates, S. (2011). Discover your CEO brand: secrets to embracing and maximizing your unique value as a leader. New York: McGraw Hill Professional.

Bendisch, F., Larsen, G., \& Trueman, M. (2013. Fame and fortune: A conceptual model of CEO brands. European Journal of Marketing, 47(3/4), 596-614. https://doi.org/10.1108/03090561311297472

Bernstein, R. S., Buse, K., \& Bilimoria, D. (2016). The Impact of CEO Tenure and Effective Board Performance on Organizational Change. American Journal of Management, 16(4), 26-38.

Brønn, P. S. (2014). How others see us: Leaders' Perceptions of Communication and Communication Managers. Journal of Communication Management, 18(1), 58-79. https://doi.org/10.1108/JCOM-03-2013-0028

Burson-Marsteller. (2003). Reputation management; CEO reputation. Retrieved from http://www.bm.com/expertise/rep_mgmt.html

Busenbark, J. R., Krause, R., Boivie, S., \& Graffin, S. D. (2016). Toward a configurational perspective on the CEO: A review and synthesis of the management literature. Journal of Management, 42(1), 234-268. https://doi.org/10.1177/0149206315618448

Campbell, C. (2004). Why Implementing a Successful CEO Communications Program is Crucial Today. Public Relations Strategist, 10(3), 32-34.

Carpenter, M. A., Geletkanycz, M. A., \& Sanders, W. G. (2004). Upper echelons research revisited: Antecedents, elements, and consequences of top management team composition. Journal of management, 30(6), 749-778. 
https://doi.org/10.1016/j.jm.2004.06.001

Chang, Y. Y., Sudipto, D., \& Gilles, H. (2010). CEO ability, pay, and firm performance. Management Science, 56(10), 1633-1652. https://doi.org/10.1287/mnsc.1100.1205

Christensen, L. T., \& Cornelissen, J. (2011). Bridging Corporate and Organizational Communication: Review, Development and a Look to the Future. Management Communication Quarterly, 25(3), 383-414. https://doi.org/10.1177/0893318910390194

Chung, K. H., Rogers, R. C., Lubatkin, M., \& Owers, J. E. (1987), "Do insiders make better CEOs than outsiders? The Academy of Management Executive, 1(4), 325-331.

Conner, C. (2018). How Top CEOs Leverage Social Media To Build A Following And Brand Loyalty. Retrieved from

https://www.forbes.com/sites/cherylsnappconner/2018/03/11/how-top-ceos-use-social-media-well/\#4bb058 $5916 \mathrm{a} 8$

Conte, F. (2018). Understanding the Influence of CEO Tenure and CEO Reputation on Corporate Reputation: An Exploratory Study in Italy. International Journal of Business and Management, 13(3), 54-66. https://doi.org/10.5539/ijbm.v13n3p54

Conte, F., Siano, A., \& Vollero, A. (2017). CEO communication: engagement, longevity and founder centrality. An exploratory study in Italy. Corporate Communications: an International Journal, 22(3), 273-291. https://doi.org/10.1108/CCIJ-10-2015-0062

Corbetta, G. (2010). Le aziende familiari. Strategie per il lungo periodo. Egea, Milano.

Daily, C. M., \& Johnson, J. L. (1997). Sources of CEO power and firm financial performance: A longitudinal assessment. Journal of Management, 23(2), 97-117. https://doi.org/10.1177/014920639702300201

Davis, R. (2015). CEO Branding: How Perception Defines Reality. London: Routledge.

Davis, R. (2018). Use CEO Branding To Gain More Visibility for Your Company. Retrieved from https://www.forbes.com/sites/forbesagencycouncil/2018/05/18/use-ceo-branding-to-gain-more-visibility-for -your-company/\#46706ca61677

Dowling, G. R. (2001). Creating corporate reputations: Identity, image, and performance. New York: Oxford University Press.

Fanelli, A., \& Misangyi, V. F. (2006). Bringing out charisma: CEO charisma and external stakeholders. Academy of Management Review, 31(4), 1049-1061. https://doi.org/10.5465/amr.2006.22528170

Feldman, R. (2004). Why Your CEO's Reputation Is Your Company's Message. The Public Relations Strategist, $10(3), 24-25$.

Ferris, G. R., Blass, F. R., Douglas, C., Kolodinsky, R. W., \& Treadway, D. C. (2003). Personal reputations in organizations. In GREENBERG J. (Ed.), Organizational behavior: The state of the science (pp. 211-246), Lawrence Erlbaum Associates, Mahwah, NJ.

Fetscherin, M. (2015). CEO branding: Theory and practice. Routledge. https://doi.org/10.4324/9781315795140

Fry, A. (1997). On one's best behavior. Marketing, 19, 25-27.

Fuller, J., \& Jensen, M. C. (2010). Just say no to Wall Street: Putting a stop to the earnings game. Journal of Applied Corporate Finance, 22(1), 59-63. https://doi.org/10.1111/j.1745-6622.2010.00261.x

Gaines-Ross, L. (2000). CEO Reputation: A Key Factor in Shareholder Value. Corporate Reputation Review, 3(4), 366-370. https://doi.org/10.1057/palgrave.crr.1540127

Gaines-Ross, L. (2003). CEO capital: A guide to building CEO reputation and company success.

Gaines-Ross, L. (2008). Corporate Reputation: 12 Steps to Safeguarding and Recovering Reputation.

Gardberg, N. A. (2017). Corporate Reputation: Fashion, Fad, or Phenomenon? Corporate Reputation Review, 20(3/4), 177-180. https://doi.org/10.1057/s41299-017-0033-4

Graffin, S. D., Wade, J. B., Porac, J. F., \& Mcnamee, R. C. (2008). The impact of CEO status diffusion on the economic outcomes of other senior managers. Organization Science, 19(3), 457-474. https://doi.org/10.1287/orsc. 1080.0354

Gray, E. R., \& Balmer, J. M. T. (1998). Managing corporate image and corporate reputation. Long Range Planning, 31(5), 695-702. https://doi.org/10.1016/S0024-6301(98)00074-0 
Grunig, J. E. (1993). Image and Substance: From Symbolic to Behavioral Relationships. Public Relations Review, 12(1), 121-139. https://doi.org/10.1016/0363-8111(93)90003-U

Hambrick, D. C. (2007). Upper Echelons Theory: An update. Academy of Management Review, 32(2), 2-10. https://doi.org/10.5465/amr.2007.24345254

Hambrick, D. C., \& Mason, P. (1984). Upper echelons: The organization as a reflection of its top managers. Academy of Management Review, 9(2), 193-206. https://doi.org/10.5465/amr.1984.4277628

Hamilton, J. T., \& Zeckhauser, R. (2004). Media coverage of CEOs: who? what? where? when? why? Working paper, Stanford Institute of International Studies.

Handler, W. (1989). Methodological issues and considerations in studying family businesses. Family Business Review, 2(3), 257-276. https://doi.org/10.1111/j.1741-6248.1989.00257.x

Hatch, M. J., \& Schultz, M. (1997). Relations between organizational culture, identity and image. European Journal of marketing, 31(5/6), 356-365. https://doi.org/10.1108/03090569710167583

Hayward, M. L. A., \& Hambrick, D. C. (1997). Explaining premiums paid for large acquisitions: Evidence of CEO hubris. Administrative Science Quarterly, 42(1), 103-127. https://doi.org/10.2307/2393810

Hayward, M. L. A., Rindova, V. P., \& Pollock, T. G. (2004). Believing one's own press: The causes and consequences of CEO celebrity. Strategic Management Journal, 25(7), 637-653. https://doi.org/10.1002/smj.405

Ibrahim, A. B. (1992). Strategy formulation in small business: A conceptual framework. Journal of Small Business and Entrepreneurship, 9(4), 71-76. https://doi.org/10.1080/08276331.1992.10600415

Ireland, R. D., \& Hitt, M. A. (2005). Achieving and maintaining strategic competitiveness in the 21 st century: The role of strategic leadership. Academy of Management Executive, 19(4), 63-77.

Jian, G., Shi, X., \& Dalisay, F. (2014). Leader-Member Conversational Quality Scale Development and Validation Through Three Studies. Management Communication Quarterly, 28(3), 375-403. https://doi.org/10.1177/0893318914533201

Kartalia, J. (1999). Technology safeguards for a good corporate reputation. Information Executive. Retrieved from http://www.entegracorp.com/downloads/Inform ation\%20Executive.pdf

Karuna, C. (2006). CEO reputation and the use of earnings-and stock-based performance measures in CEO evaluation. Working Paper, University of California at Irvine. https://doi.org/10.2139/ssrn.921529

Karuna, C. (2009). CEO reputation and internal corporate governance. Working Paper, The Paul Merage School of Business.

Kitchen, P. J., \& Laurence, A. (2003). Corporate reputation: An eight-country analysis. Corporate Reputation Review, 6(2), 103-117. https://doi.org/10.1057/palgrave.crr.1540193

Ladd, B. (2018). Will The Real Elon Musk Please Stand Up? Retrieved from https://www.forbes.com/sites/brittainladd/2018/07/16/will-the-real-elon-musk-please-stand-up/\#e7d782b54 c31

Lee, S. (2006). CEO reputation: who benefits-the firm or the CEO? Working paper, University of Southern California.

Lo, F. Y., \& Fu, P. H. (2016). The interaction of chief executive officer and top management team on organization performance. Journal of Business Research, 69(6), 2182-2186. https://doi.org/10.1016/j.jbusres.2015.12.027

Love, E. G., Lim, J., \& Bednar, M. K. (2017). The face of the firm: The influence of CEOs on corporate reputation. Academy of Management Journal, 60(4), 1462-1481. https://doi.org/10.5465/amj.2014.0862

Lovelace, J. B., Bundy, J., Hambrick, D. C., \& Pollock, T. G. (2018). The shackles of CEO celebrity: Sociocognitive and behavioral role constraints on "star" leaders. Academy of Management Review, 43(3), 419-444. https://doi.org/10.5465/amr.2016.0064

Malmendier, U., \& Tate, G. (2005). CEO overconfidence and corporate investment. The Journal of Finance, 60(6), 2661-2700. https://doi.org/10.1111/j.1540-6261.2005.00813.x

Mcknight, P. J., Tomkins, C., Weir, C., \& Hobson, D. (2000). CEO age and top executive pay: A UK empirical study. Journal of Management and Governance, 4(3), 173-187. https://doi.org/10.1023/A:1026755428942 
Melewar, T. C., \& Karaosmanoglu, E. (2006). Seven dimensions of corporate identity: A categorization from the practitioners' perspective. European Journal of Marketing, 40(7/8), 846-869. https://doi.org/10.1108/03090560610670025

Men, L. R. (2012). CEO credibility, perceived organizational reputation, and employee engagement. Public Relations Review, 38(1), 171-173. https://doi.org/10.1016/j.pubrev.2011.12.011

Meng, J., \& Berger, B. K. (2013). What they say and what they do: Executives Affect Organizational Reputation through Effective Communication. In CARROLL C. E. (Ed.), The Handbook of Communication and Corporate Reputation (pp. 06-317). https://doi.org/10.1002/9781118335529.ch26

Milbourn, T. T. (2003). CEO reputation and stock-based compensation. Journal of Financial Economics, 68(2), 233-262. https://doi.org/10.1016/S0304-405X(03)00066-7

Murray, K., \& White, J. (2005). CEOs' views on reputation management. Journal of Communication Management, 9(4), 348-358. https://doi.org/10.1108/13632540510621687

Naldi, L., Cennamo, C., Corbetta, G., \& Gomez-Mejia, L. (2013), "Preserving socio-emotional wealth in family firms: Asset or liability? The moderating role of business context. Entrepreneurship Theory and Practice, 37(6), 1341-1360. https://doi.org/10.1111/etap.12069

Norman, S. M., Avolio, B. J., \& Luthans, F. (2010). The impact of positivity and transparency on trust in leaders and their perceived effectiveness. The Leadership Quarterly, 21(3), 350-364. https://doi.org/10.1016/j.leaqua.2010.03.002

Ohanian, R. (1990). Construction and validation of a scale to measure celebrity. Journal of Advertising, 19(3), 39-52. https://doi.org/10.1080/00913367.1990.10673191

Pancer, S. M., Brown, S. D., \& Barr, C. W. (1999). Forming impressions of political leaders: A cross-national comparison. Political Psychology, 20(2), 345-368. https://doi.org/10.1111/0162-895X.00148

Park, D. J., \& Berger, B. K. (2004). The presentation of CEOs in the Press, 1990-2000: Increasing salience, positive valence, and a focus on competency and personal dimensions of image. Journal of Public Relations Research, 16(1), 93-125. https://doi.org/10.1207/s1532754xjprr1601_4

Parrino, R. (1997). CEO turnover and outside succession a cross-sectional analysis. Journal of financial Economics, 46(2), 165-197. https://doi.org/10.1016/S0304-405X(97)00028-7

Pincus, J. D., Robert, A. P., Rayfield, A. P., \& Debonis, J. P. (1991). Transforming CEOs into Chief Communication Officers. Public Relations Journal, 47(11), 22-27.

Pinvidic, B. (2018). The Celebrity CEO - Why Branding Yourself Is As Important As Branding Your Company. Retrieved from https://www.forbes.com/sites/brantpinvidic/2018/04/16/the-celebrity-ceo-why-branding-yourself-is-as-impo rtant-as-branding-your-company/\#3debf0b35fb3

Power, J. (2005). Incongruency e Ruthless Brands: Modelling the effects of trust on the customer - company", Eight Annual Conference of the Irish Academy of Management, Galway - Mayo Institute of Technology 7th - 9th September.

Rampersad, H. K. (2009). Authentic personal branding: A new blueprint for building and aligning a powerful leadership brand. Charlotte, NC.

Ranft, A. L., Zinko, R., Ferris, G. R., \& Buckley, M. R. (2006). Marketing the image of management: The costs and benefits of CEO reputation. Organizational Dynamics, 35(3), 279-290. https://doi.org/10.1016/j.orgdyn.2006.05.003

Reputation Institute. (2017). Global RepTrak 100. TheWorld's Most Reputable Companies. Retrieved from http://www.ideeideas.it/press/global_reptrak_2017.pdf

Rindova, V. P., Williamson, I. O., Petkova, A. P., \& Sever, J. M. (2005). Being good or being known: An empirical examination of the dimensions, antecedents, and consequences of organizational reputation. Academy of Management Journal, 48(6), 1033-1049. https://doi.org/10.5465/amj.2005.19573108

Roberts, P. W., \& Dowling, G. R. (2002). Corporate reputation and sustained superior financial performance. Strategic Management Journal, 23(12), 1077-1093. https://doi.org/10.1002/smj.274

Serfling, M. A. (2014). CEO age and the riskiness of corporate policies. Journal of Corporate Finance, 25, 251-273. https://doi.org/10.1016/j.jcorpfin.2013.12.013 
Shane. S., \& Cable. D. (2002). Network Ties, Reputation, and the Financing of New Ventures. Management Science, 48(3), 364-381. https://doi.org/10.1287/mnsc.48.3.364.7731

Shen, W., \& Cannella, A. A. (2002), "Revisiting the performance consequences of CEO succession: The impacts of successor type, post-succession senior executive turnover, and departing CEO tenure. Academy of Management Journal, 45(4), 717-733.

Shi, W., Zhang, Y., Hoskisson, R. E. (2017). Ripple effects of CEO awards: Investigating the acquisition activities of superstar CEOs' competitors. Strategic Management Journal, 28(10), 2080-2102. https://doi.org/10.1002/smj.2638

Sohn, Y., Lariscy, R. W., \& Tinkham, S. F. (2009), "The impact of CEO reputation: Negative news and economic decisions. International Journal of Strategic Communication, 3(1), 1-18. https://doi.org/10.1080/15531180802606596

Ulrich, D., \& Smallwood, N. (2007). Leadership Brand: Developing Customer-Focused Leaders to Drive Performance and Build Lasting Value. Boston: Harvard Business School Press.

Van der Jagt, R. (2005). Senior Business Executives See Communication and Reputation as a Crucial Part of Their Leadership Role. Corporate Reputation Review, 8(3), 179-186. https://doi.org/10.1057/palgrave.crr.1540248

Vera, D., \& Crossan, M. (2004). Strategic leadership and organizational learning. Academy of management review, 29(2), 222-240. https://doi.org/10.5465/amr.2004.12736080

Waldman, D. A., Ramirez, G. G., House, R. J., \& Puranam, P. (2001). Does leadership matter? CEO leadership attributes and profitability under conditions of perceived environmental uncertainty. Academy of management journal, 44(1), 134-143. https://doi.org/10.1111/j.1467-6486.2006.00642.x

Waldman, D. A., Siegel, D. S., \& Javidan, M. (2006). Components of CEO Transformational Leadership and Corporate Social Responsibility. Journal of Management Studies, 43(8), 1703-1725.

Watson, T. (2007). Reputation and ethical behaviour in a crisis: predicting survival. Journal of Communication Management, 11(4), 371-384. https://doi.org/10.1108/13632540710843959

Weng, P. S., \& Chen, W. Y. (2017). Doing good or choosing well? Corporate reputation, CEO reputation, and corporate financial performance. The North American Journal of Economics and Finance, 39, 223-240. https://doi.org/10.1016/j.najef.2016.10.008

Westley, F., \& Mintzberg, H. (1989). Visionary leadership and strategic management. Strategic Management Journal, 1(1), 17-32. https://doi.org/10.1002/smj.4250100704

Williams, P. A. (1996). The relation between a prior earnings forecast by management and analyst response to a current management forecast. The Accounting Review, 71(1), 103-113.

Yim, S. (2013). The acquisitiveness of youth: CEO age and acquisition behavior. Journal of financial economics, 108(1), 250-273. https://doi.org/10.1016/j.jfineco.2012.11.003

Zerfass, A., \& Sherzada, M. (2015). Corporate communications from the CEO's perspective: How top executives conceptualize and value strategic communication. Corporate Communications: An International Journal, 20(3), 291-309. https://doi.org/10.1108/CCIJ-04-2014-0020

Zerfass, A., Verčič, D., \& Wiesenberg, M. (2016), Managing CEO communication and positioning: A cross-national study among corporate communication leaders. Journal of communication management, 20(1), 37-55. https://doi.org/10.1108/JCOM-11-2014-0066

Zhang, Y., \& Rajagopalan, N. (2010). Once an outsider, always an outsider? CEO origin, strategic change, and firm performance. Strategic Management Journal, 31(3), 334-346. https://doi.org/10.1002/smj.812

\section{Copyrights}

Copyright for this article is retained by the author(s), with first publication rights granted to the journal.

This is an open-access article distributed under the terms and conditions of the Creative Commons Attribution license (http://creativecommons.org/licenses/by/4.0/). 